EXAMINING EFL CLASSROOM INTERACTION

BASED ON SINCLAIR AND COULTHARD MODEL

AN ARTICLE

Submitted as the Partial Fulfillment of the Requirements for the Degree of Sarjana Pendidikan

By:

NURUL WULANDA

Registration Number: 2122121052

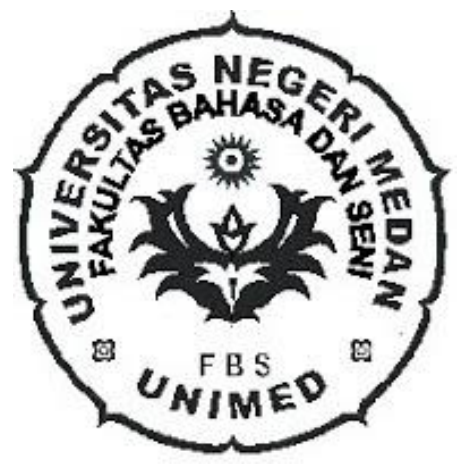

ENGLISH AND LITERATURE DEPARTMENT

FACULTY OF LANGUAGES AND ARTS

STATE UNIVERSITY OF MEDAN

2017 


\section{ARTIKEL}

\section{EXAMINING EFL CLASSROOM INTERACTION BASED ON SINCLAIR AND COULTHARD MODEL}

Disusun dan Diajukan oleh:

Nurul Wulanda

NIM. 2122121052

Telah diverifikasi dan dinyatakan memenuhi syarat

untuk diunggah pada jurnal online

Medan, Februari 2017

Menyetujui

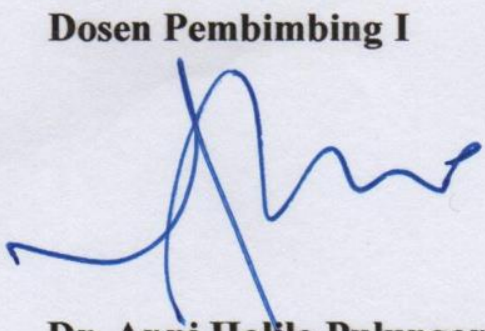

Dr. Anni Holila Pulungan, M.Hum. NIP. 197005222001122001
Dosen Pembimbing II

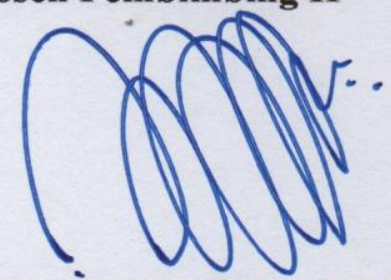

Isli Iriani Indiah Pane, S.Pd., M.Hum. NIP. 197908022005012003

Ka. Prodi Studi

Pendidikan Bahasa Inggris

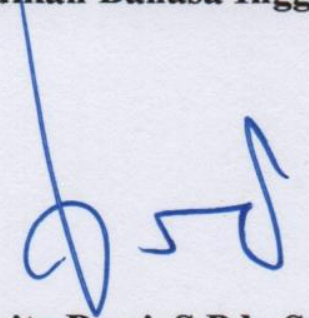

Nora Ronita Dewi, S.Pd., S.S., M.Hum.

NIP. 198005222008122003 


\title{
EXAMINING EFL CLASSROOM INTERACTION \\ BASED ON SINCLAIR AND COULTHARD MODEL
}

\author{
*Nurul Wulanda \\ **Dr. Anni Holila Pulungan, M.Hum. \\ **Isli Iriani Indiah Pane, S.Pd.,M.Hum.
}

\begin{abstract}
The aim of this study were (a) to identify classroom discourse patternings of EFL classroom interaction based on Sinclair and Coulthard Model, and (b) to describe how EFL classroom interaction affects the students' learning process based on Sinclair and Coulthard Model. The subject of this study were an English Teacher, and 40 students of XI MIA 1, SMA Swasta Nurul Iman. The instrument for collecting data were observation and recording. The result of this research were the following, (a) it was found that in the classroom discourse, there were seven patterns initiated by the teacher and four patterns initiated by the student as the IRF (Initiation-Response-Feedback) was used more often by the teacher, (b) the interaction affects the teaching learning process in a way how the lesson passed on to the student affects the goal of learning English itself to be able to use English both inside and outside the classroom. It can be concluded that the students were not getting used to interact with English, and the goal of communicative skill in English was not achieved. Thus, the teachers should reorganize the activities which can foster more interaction by using English in the classroom.
\end{abstract}

Keywords: Classroom interaction, classroom discourse, Sinclair and Coulthard, IRF Pattern.

\footnotetext{
*Graduate Status

**Lecturer Status
} 


\section{INTRODUCTION}

\section{Background of the Study}

Students' learning takes place through communication system with others as cognitive process of constructing knowledge and developing competency to understand, reason, and solve problem (Markee, 2015, p.96).

The communication system in the classroom itself is hold by the interaction among teacher and students. Therefore, the interaction in the classroom is quite different with ordinary interaction. The study of that communication system is the study of classroom discourse.

In the classroom it is usually the teacher who decides who will speak, and for how long. When the teacher decides to ask a question, the teacher tend to know the answer. The aim of asking the question is to evaluate the student's competency. Therefore, what actually happen in the classroom will determine the outcome of the learning that is realized in real life. The students in the classroom is subject to the norms of classroom context, language and discourse whereas in the same trying to acquire a different set of conventions, language and discourse patterns that will be acceptable outside the classroom. Briefly speaking, for the students of English as a foreign language like in Indonesia where English plays no major role in the community and is primarily learnt only in the classroom, the students still need to learn English in order to use it in social context. The distinctions of linguistic structure of discourse have been shown by Sinclair and Coulthard (1975) that classroom has by nature a tripartite structure: the teacher initiates, the pupil responds, the teacher then evaluate the response. 
In Indonesia where English is as Foreign Language and taught from elementary to high school, the goal of learning English, especially for Senior High School student based on Materi Pelatihan Guru Implentasi Kurikulum 2013 Tahun 2015: Mata Pelajaran Bahasa Inggris is,

"Tujuan mata pelajaran Bahasa Inggris di sekolah menengah adalah untuk mengembangkan potensi peserta didik agar memiliki kompetensi komunikatif dalam wacana interpersonal, transaksional, dan fungsional, dengan menggunakan berbagai teks berbahasa Inggris lisan dan tulis, secara runtut dengan menggunakan unsur kebahasaan yang akurat dan berterima, tentang berbagai pengetahuan faktual dan prosedural, serta menanamkan nilai-nilai luhur karakter bangsa, dalam konteks

kehidupan di lingkungan rumah, sekolah, dan masyarakat."

(Rohim, 2015, p.16)

Unfortunaltely, based on author's teaching experience when doing Teaching Practice in SMA Negeri 1 Babalan, the students often became reluctant to participate in a classroom interaction due to their lack of convention of turntaking as the signals of their interactions with each other and with the teacher. Firstly, because they either did not know how to respond or say something in English. Secondly, as the author's finding, the students felt less confident to say something in English. The EFL students barely participated in their verbal interactions. Turns were rarely more than several clauses, and there were frequently extended periods of silence as the teacher wrote notes on the whiteboard. In addition, students mostly used natural language with each other and the teacher which causing no practice in constructing their own question and response. Supported by Huraerah's findings in her research at in one of Senior High School in Bandung, it was revealed that the percentage of teacher talk was more than 54\% (2013). Also the research from Qingdao University which 
resulting that teacher-initiated exchanges dominated in classroom dicourse patterns (Yu, 2009, p.154).

In attempt to understand those such classroom interaction that can be very mechanical even monotonous, understanding possible contributing pattern of classroom discourse would give benefit by enabling the teacher to evaluate their own output as the teacher and that of their students the EFL classroom. One of the most important features of all classroom discourse is that it follows a fairly typical and predictable structure, comprising three parts: a teacher initiation, a student response, and a teacher feedback, commonly known as IRF. This three-part structure was first put forward by Sinclair and Coulthard in 1975 and is known as the IRF exchange structure. The work of Sinclair and Coulthard had a huge impact on the understanding of the ways in which teacher and students communicate.

Classroom discourse analysis is useful for a teacher to understand the form of discourse classroom pattern, the teacher get understanding of the ways story can be told, questions can be responded to, and problem can be solved. This study aids their teaching patterns in a way that will encourage interactions among students and improved classroom performance especially for teaching and learning English as Foreign Language.

\section{REVIEW OF LITERATURE}

English as Foreign Language is taught in schools, often widely, but it does not play an essential role in national or social life. Although, very often EFL 
(English as Foreign Language) is interchangeable with ESL (English as a Second Language). Thus to distinguish operationally between EFL and ESL, it is necessary to think that the contexts are in the classroom. ESL context those in which the classroom target language is readily available outside the classroom. As for the previous example, teaching English in India and Singapore fall into ESL category. EFL contexts are those which students do not have ready-made contexts beyond their classroom (Munaz and Collins, 2016, p.134).

Classroom can be characterized and described by looking at a range of interactional features such as teacher elicitation strategies, learner responses and teacher evaluations (Walsh, 2011, p. 25). In terms of the English, there are two kind of classroom, which are language Classroom and the content classroom. In content classroom, English is used in subjects like geography or physics. While in language classroom as EFL falls into this category, the language is used both as the subject and in interacting among others. In fact, interaction is the heart of communication; it is what the communication is all about. Thus, interaction is promoted in the ways in which language is used (Walsh, 2012, p.3).

Discourse analysis is concerned with the study of the relationship between language and the contexts in which it is used. Discourse that happened in the classroom is classroom discourse. Classroom discourse analysis is an aspect of classroom proses research, which is one way for teachers to monitor both the quantity and quality of students' output.

In the field of educational language research, the words 'discourse analysis' are attached to the names of Sinclair and Coulthard model of description 
of the teacher-student talk. The discourse level of this model includes five ranks, a lesson refers to everything that takes place in the classroom from the point the teacher enters until she/he leaves and is made up of a series of transactions, which in turn is made up of a number exchange. Exchange generally consists of the IRF (Initiate-Response-Feedback) exchange pattern and is realized by eliciting, informing and directing moves. Exchange then, is made up of a number of moves. Moves are made up acts. Acts are the smallest units of analysis and can take on many different functions within the move. In particular form of classroom interactions, the teaching exchange, is considered among the most frequently occurring types of teacher-student talk in the classroom which is called InitiationResponse-Feedback (IRF) —An Initiation by the teacher, followed by a Response from the student, followed by Feedback to the student's response from the teacher. In this three-part exchange, the teacher's questions require the student to recite previously learned item. IRF may also be used to see if students know a certain word or linguist item. IRF challenge students to think, reason, and make connections (Christoper and Mercer, 2001, p.94). The IRF itself is the patterning of the classroom discourse.

\section{RESEARCH METHODOLOGY AND FINDINGS}

\section{Methodology}

This research was conducted by using qualitative research. Auerbach and Silverstein (2003) stated that, "Qualitative research is research that involves 
analyzing and interpreting texts and interviews in order to discover meaningful patterns descriptive of a particular phenomenon" (p. 3).

Discourse analysis analyses classroom discourse in linguistic terms through the study of classroom transcripts which are assigned utterances to discourse pattern of Sinclair and Coulthard Model (1975) in the verbal behaviors of both teachers and students participating in EFL classroom and its focus is on words and utterances above the level of sentence and its main aim is to look at the ways in which words and phrases function in context (Walsh, 2011, p.81). The data were analyzed in the form of descriptive. The researcher transcribed the video-recording, since this study aimed to examine the interaction within classroom. Furthermore, the data were focused on the teaching learning process by analyzing the interactional conversation among teacher-students and studentsteacher by using Sinclair and Coulthard Initiation-Response-Feedback (IRF) model. The researcher, as an observer, recorded the process of teaching English in the classroom.

\section{Techniques of Analyzing the Data}

The data obtained was analyzed by using the analysis procedures according to Rymes as follows (Rymes, 2009, p.74):

1. Recording real classroom interaction. The researcher recorded the whole part of teaching and learning process in order to get the teacher and students talk during the interaction in the classroom. 
2. Viewing interaction and making preliminary observations. The researcher observed the interaction by taking field notes to see event that is not catches up by the recording. Viewing interactional involved on focal event, to look at how it is patterned, and the sequences within it.

3. Transcribing the talk and action. Transcribing-writing down what everyone said. Transcripts represented social context, whether or not we intend them to.

4. Analyzing transcript. Analyzing transcript can be defined as coding scheme, which the researcher analyzed the pattern of the talk in the transcript by using Sinclair and Coulthard model (1975), and then analyzing how interaction affect the direction classroom discourse takes.

5. The conclusion was drawn from the data that have been summed up and making the report of the research.

The researcher used qualitative research. To answer the problem of the study, the researcher used discourse analysis in the form of descriptive data by applying Sinclair and Coulthard Model to interpret the data.

\section{Findings}

1. From the data analysis the researcher found that the classroom discourse patterning of EFL classroom interaction based on Sinclair and Coulthard model (1975) in this study appeared to be seven patterns initiated by the 
teacher and four patterns initiated by the student in the sense that the dominance in IRF pattern initiated by the teacher by $30.62 \%$.

2. Secondly, it is revealed that the interaction is still dominated by the teacher which was shown from the transcript and percentage from the IRF patterning itself, which were initiated mostly by the teacher, with the teacher asking questions, calling on the students to answer and the students giving answers which were then followed by the teacher's feedback. In addition, the student actually speaks to follow what the teacher said or finishing what the teacher said, and made noises. The effect of the regarding issue is the goal of learning English especially to EFL students to use English as verbal communication inside and outside the classroom cannot be achieved.

\section{CONCLUSION AND SUGGESTIONS}

\section{Conclusion}

Based on the data analysis it was found that the classroom discourse patterning of EFL classroom at XI MIA 1 SMA Nurul Iman, based on Sinclair and Coulthard model (1975) was dominated by IRF (Initiation-ResponseFeedback) patterning initiated by the teacher $(30.62 \%)$ in the sense of teacherdominated the classroom interaction. It was found that there were seven patterns initiated by the teacher, meanwhile there were only four patterns initiated by the student. 
The EFL classroom interaction affect the students' learning process can be seen in terms with the categories that are mostly used by the teacher, it can be concluded that the teacher's roles are as manager, director, facilitator, and controller, in other words teacher-centered, meanwhile Curriculum 2013 agreed to be student-centered. The interaction affects the teaching learning process in a way how the lesson passed on to the student. In this study, it was found that the teacher mostly used Bahasa as the medium of interaction along with the students. The goal of learning English is to be able use English inside and outside the classroom. So, if the teacher did not make the students get used to speak in English by using it himself/herself both as medium and the subject in the classroom interaction, it will affect the goal of learning English itself is not accomplished. If the teacher is to prepare the students for real-world communication, the teacher need to develop awareness of the language produced inside the classroom and the types of roles that the teacher might possibly be limiting the students to.

\section{Suggestions}

After the researcher carried out the research, she would like to give suggestion related to the result of this research. Hopefully it can be applied easily in teaching and learning activity and decrease the errors.

1) The teachers should reorganize the activities which can foster more interaction in the classroom, such as brainstorming and problem-solving, role play, simulations, and discussion. Using such activities in the classroom, teachers will be able to motivate students to learn in a more 
involving way. These kinds of activities can provoke a very positive attitude towards language learning since they resemble real life events. Moreover, students must be persuaded to interact positively and effectively in the language classroom. Teachers should incorporate more real life like activities into their teaching practice.

2) The institution should provide the English textbooks by trying to incorporate activities and tasks in the books which would provoke more 'genuine communication' between teachers and students.

3) English is very important which needs practice. Therefore, the students should should be daring to speak in English, because in the classroom they are allowed to do mistake, and less outside the classroom. In other word, interaction in the classroom will provide them the chance to participate in English communication in society.

4) This research is not too complete yet and needs additional explanation. Therefore, other researchers should conduct further studies on classroom discourse whether it is based on Sinclair and Coulthard model, which will be a very useful reference to the students' needs in teaching learning process. 


\section{REFERENCES}

Auerbach, C. F., and Silverstein, L. B. (2003). An Introduction to Coding and Analysis: Qualitative Data. New York: New York University.

Collins, L., and Munoz, C. (2016). The Foreign Language Classroom: Current Perspective and Future Considerations. The Modern Language Journal. 100 (16), 133-147.

Coulthard, M. (1977). An Introduction to Discourse Analysis. London.

Coulthard, M. (1992). Advances in Spoken Discourse Analysis. London: Routledge.

Coulthard, M. and Brazil, D. (1992). Exchange Structure. In Coulthard. M, Advances in Spoken Discourse Analysis. London: Routledge.

Edward, D. and Mercer, N. (1993). Common Knowledge: The Development of Understanding in the Classroom. New York: Routledge.

Huraerah, N.R. (2013). The Analysis of Verbal Interaction between Teacher and Students in The Classroom. Thesis, Bandung: Universitas Pendidikan Indonesia.

Huraerah, N. 2013. The Analysis of Verbal Interaction between Teacher and Students in the Classroom. Thesis, Universitas Pendidikan Indonesia.

Markee, N. (2015). The Handbook of Classroom Discourse and Interaction. United Kingdom: John Wiley \& Sons Ltd.

Rohim, F. (2015). Materi Pelatihan Guru Implementasi Kurikulum 2013 Jenjang SMA/SMK Tahun 2015: Mata Pelajaran Bahasa Inggris. Kementerian Pendidikan dan Kebudayaan.

Rymes, B. (2009). Classroom Discourse Analysis: A Tool for Critical Reflection. New York : Hampton Press.

Saragih, A. (2015). Discourse Analysis: A Systemic Functional Linguistic Approach to the Analysis of Discourse and Text. Medan.

Sinclair, J. and Coulthard, M. (1992). Towards an analysis of discourse. In Coulthard. M, Advance in Spoken Discourse Analysis. London: Routledge.

Walsh, S. (2011). Exploring Classroom Discourse Language in Action. London: Routledge.

Walsh, S. (2006). Investigating Classroom Discourse. London: Routledge.

Yu, W. (2009). An Analysis of College English Classroom Discourse. CCSE: Asian Social Science, 5(7), 152-159. 